\title{
Sunken cities: climate change, urban futures and the imagination of submergence
}

\author{
Paul Dobraszczyk
}

\section{Keywords}

Imagination, Futures, Flooding, Climate change, Architecture, Art, Fiction

\begin{abstract}
Climate change presents multiple challenges to cities; not only in terms of the resilience and sustainability of the urban fabric, but also in relation to how urban inhabitants imagine how they might adapt to a future transformed urban environment. This article explores imaginative modes of thinking in relation to future cities and climate change, focusing on representations of urban drowning or submergence. It considers in turn, climate-change fictions - from J. G. Ballard's The Drowned World (1962) to Paulo Bacigalupi's The Drowned Cities (2012); visual representations from Gustave Doré’s ‘The New Zealander' (1872) to Alexis Rockman's Manifest Destiny (2004); and architectural conjecture, from Wolf Hilbertz' Autopia Ampere (1970-) to CRAB Studio's Soak City (2009). In drawing out how these imaginaries intersect with theoretical understandings of science fiction and ecology, this article contends that an emphasis on multiple imaginaries of climate change is critical in expanding the narrow range of possibilities that currently characterise the literature on cities and climate change. Imaginative texts, images and designs mutually inform each other to encourage holistic ways of approaching how we think about the future prospect of urban submergence and to incubate radical responses to it.
\end{abstract}

\section{Sunken cities: climate change, urban futures and the imagination of submergence}

Despite the fact that climate change is already affecting cities across the world - principally increased incidence and severity of urban flooding - it nevertheless remains a discourse dominated by future predictions. Even by the cautious estimates of the most recent report by the Intergovernmental Panel on Climate Change (IPCC) in 2014, cities are in for a rough ride in the next century. By 2100, the rise in global temperatures is likely to exceed 2 degree Celsius above pre-industrial levels and reached that level for a short time in early 2016 (Holthaus, 2016); sea levels will rise anything up to a metre, even more if current predictions prove to be over-optimistic; the sea will also warm and become more acidic; and the turbulence of the atmosphere will intensify, leading to more extreme weather events, and greater risks of flooding (IPCC, 2014). As much as these climate reports are grounded in empirical evidence, they are nevertheless essentially predictive in their discourse, laying out a whole host of possible futures that rely as much on our 
ability to imagine those futures, even with the help of a welter of facts and figures (Yusoff and Gabrys, 2011: 516-34). The overwhelmingly future-orientated discourse of climate change is perhaps the principal reason why it has been and continues to be so difficult to find common agreement as to how to act in the face of such fundamentally uncertain futures (Hulme, 2009; Machin, 2013).

It is no wonder then that the focus of much of the current literature on climate change and cities is on mitigation rather than adaptation, with Bulkeley (2013: 143) admitting that, even as the effects of climate change are already being felt, international and national policy-making communities are still more concerned with mitigating these effects rather than adapting to them (and this formed the focus of the landmark international climate change agreement in Paris at the end of 2015). Even the emerging body of literature on climate change and urban resilience, perhaps most notably the ongoing Resilient Cities congress and its associated publications (OttoZimmermann, 2011), which seeks to shift the focus from mitigation to adaptation, remains firmly grounded in instrumental thinking - whether that centres on the adaptation of the built fabric through long-term strategic planning (Watson and Adams, 2010) or the re-shaping of urban governance and socio-political life towards sustainable ends (Pelling, 2011). Whilst these objectives are laudable, what is underplayed in much of this work is the role of the creative imagination in thinking through the relationship between urban futures and climate change. Engaging the imagination - 'the human power to connote absence into presence, actuality into possibility' (Kearney, 1991) - with the discourse of climate change and cities is critical because the imagination is a powerful tool for articulating radical new possibilities for urban life in the face of equally radically uncertain futures. Thus, despite the denigration of future-oriented modes of urban planning in architectural modernism (and their perceived authoritarian utopianism), there is obviously a pressing need to re-engage the imagination of future cities in ways that reinvigorate 'blue-sky thinking', as Vidal and Cornils (2014) term it. Indeed, the impulse for radical urban change has been recently reassessed by critics such as Jameson (2008), Harvey (2000) and Levitas (2013). They regard an invigorated form of utopian futurism as a necessary response to the apparent hegemony of global capitalism which has arguably contributed most to the engines that are driving climate change. Far from escaping into fantasies of alternate, yet implausible, worlds, the utopian mode (and its close cousin dystopia) might be the only way of arguing that radical difference is possible and that alternatives to global capitalism are achievable (Jameson, 2008: 231-32).

The multiple urban imaginaries that form the focus of this article contribute to a contemporary reevaluation of science fiction as an important tool in the discourse of urban planning. For example, Stephen Graham's recent work on vertical urbanism has argued that science fiction cities are 'pivotal in constituting the materialities of contemporary cities' because 'built projects, material cities, sci-fi text, imaginary futures, architectural schemes and urban theories mingle and resonate together in complex and unpredictable ways' (Graham, 2016: 388). 
This intermingling is crucial to the power of science fiction in that it produces what science-fiction theorist Darko Suvin has termed 'cognitive estrangement', namely the process of temporarily taking readers and viewers out of the real world they inhabit into an imagined one that seems strange and disjointed, but nevertheless convincing in its familiarity (Suvin, 1972). When we read a text, watch a film or look at an image of a future city, we are not escaping from the real, but rather redefining its parameters by creating links between imagined and real cityscapes that make any clear separation between the two categories untenable. In Graham's estimation, 'real and imagined sci-fi cities...offer powerful opportunities for progressively challenging contemporary urban transformation' because they hold, at their core, the value of multiplicity rather than the homogeneity of urbanism under global capitalism, and they emphasise the forging of linkages rather than the cutting of ties in an increasingly fragmented world (Graham, 2016: 395).

Taken together, the themes and works explored here aim to establish resonances between a wide range of urban imaginaries that engage, whether explicitly or obliquely, with the transformed urban environments that will likely be brought about by climate change. I contend that the emphasis here on multiple imaginaries of climate change - here represented through literature, art and the architectonic - is critical in expanding the narrow range of possibilities that currently characterise the literature on cities and climate change. To expand these possibilities is not merely to add another layer of interpretation onto the scientific or instrumentalist - an aesthetic embellishment of the pragmatic; rather, it contributes to the redrawing of the boundaries of the entire field of thinking about climate change, particularly with respect to how it affects our psyches - our thinking and feeling about the subject. This emphasis on the mind is important because it chimes with philosopher Félix Guattari's reading of ecology - or what he terms 'ecosophy' - as the coming together of individual subjectivity, social relations and the environment (Guatarri, 1989). For Guattari, an ecology of the mind means one that resists the tendency of contemporary capitalism or, by implication, any dominating worldview, to limit the human imagination by subjugating it to ideological dictates. Correlating with Jacques Rancière's understanding of aesthetics as inseparable from politics (Rancière, 2004), Guattari argues that the imagination is already politicised because, as a faculty that only flourishes when set free, it is inherently antithetical to such subjugation. Furthermore, as an emancipatory tactic, the imagination gives credence to multiple subjectivities - whether Guattari's heterogenous mental ecologies or Rancière's modes of being and 'forms of visibility' - making it harder for any single narrative to dominate our understanding of a given historical event, place or group of people. Of course, cohering these subjectivities into a collective form is intensely problematic and always risks diminishing the multiple into something lesser. Yet, in order to fully embrace what happens when we encounter the future-orientated discourse of climate change, we must begin in the only place we can, that is, facing outwards from our own subjective imaginative worlds, ready to engage with whatever we encounter. From that place, we can aim to find resonances with others' subjectivities and build a collective basis for re-inhabiting our cities in new and inventive ways. 


\section{Climate-change fictions}

Even as the recent knowledge of climate change has generated many future imaginings of drowned cities, particularly coastal or low-lying conurbations, these are also part of a long history of collective fears of apocalyptic inundations that date back to pre-history in countless stories of devastating deluges that characterise so many of the world's religious and spiritual traditions (Withington, 2013: 9-32). These ur-floods may have grown from myths and legends but their almost universal presence in diverse geographical locations and cultural traditions reflect the fact that floods are the most common disasters known to man (19-20). Thus, even as the most famous submerged city of Atlantis was probably a mythic assemblage of classical architectures buried under the city's namesake ocean, it was probably also inspired by real urban drownings in the ancient world, whether cities submerged by flood waters or others buried by Vesuvius's ash and mud (Donnelly, 2006). Throughout history, vulnerable cities have been literally obliterated by the seas - the archaeologist and scuba diver's paradise off the coast of Alexandria testament to rising sea levels that drowned ancient cities; ${ }^{i}$ the city of Saeftinghe in the Netherlands and Dunwich in England to more recent ones, the former being devastated in the All Saints Flood of 1750 (never to be recovered), the later slowly erased by relentless coastal erosion (Anderson, 2015: 198-205). More recently, some cities have been given up to others in the demand for fresh water: for example Shi Cheng, the Lion City, which lies in ruins at the bottom of a hydroelectric dam in China, or the city of Igarata in Brazil, submerged since 1969 after the creation of a reservoir but which recently started to re-emerge after one of the worst droughts in recent history (Osborne, 2015).

The prospect of future drownings due to the effects of climate change, principally rises in sea levels caused by melting ice in the polar regions and Greenland, has been a dominant motif in climate-change fictions, probably because it chimes with this long history of real and imagined drowned cities as well as providing a way of rendering the effects of climate change in a local context and as a powerful, if often exaggerated, effect (Abbott, 2016: 160-70; Trexler, 2015: 83-4). Within this body of work, two types of narratives dominate; on the one hand, post-diluvian cityscapes imagined in the future after a catastrophic flood; on the other, the progress of a flood that gradually transforms an urban environment. In the first category, the most influential precedent is J. G. Ballard's early novel The Drowned World, published in 1962. Although written long before global warming was even coined as a term (in 1975), the novel has come to be regarded as a major influence on more recent climate change fictions and also prescient of real climaterelated disasters, such as the devastation of New Orleans after Hurricane Katrina in 2005 (Gandy, 2006: 86; Ballard, 2009). Ballard also self-consciously positioned the novel within an existing English literary tradition of imagining London's death by water, from Richard Jefferies's 1885 fantasia After London to John Wyndham's The Kraken Wakes (1953). Yet, in explicit contrast to Wyndham's novel, which emphasises survival and rebuilding, and to the more recent reconstruction in post-Katrina New Orleans, where flood defences have been strengthened, The 
Drowned World posits a transformed urban world that must be adapted to in order for an authentic human experience to emerge (Sellars \& O’Hara, 2014: 83, 90).

Ballard's novel presents a hallucinatory vision of a future London that has been sunk beneath vast flood waters created by the melting of the polar ice sheets, the latter caused by rapid global warming that resulted from a sudden increase in solar radiation. The Drowned World imagines London as a city that has been literally swamped by exotic flora and fauna that has reverted back to resemble that of the Paleozoic era: an 'impenetrable Matto Grosso sometimes three hundred feet high' (Ballard, 2011: 19) that consumed the city's half-submerged steelsupported tower blocks; giant iguanas that made their homes in the boardrooms of former offices; outsized bats that created their eyries in the ruined buildings; and, in between the last vestiges of the city, a network of lagoons filled with rotting vegetation and the carcasses of dead animals. Living in the former Ritz Hotel, the novel's isolated protagonist, Kerans, is part of a group of scientists that are gathering information about the world's drowned cities before heading to the last remaining place fit for human habitation - the arctic - where the remnants of humanity have gathered. With the temperatures and humidity rising each day, Kerans experiences his own psychic equivalent of regression, eventually embracing the new jungle before him, the novel concluding with this 'second Adam' heading south towards his certain death. Key to Ballard's vision and the power of his prose is the way in which the transformed urban environment functions as a mirror image of the processes going on in Kerans's psyche, whether in his constant confrontation with the submerged city itself (an obvious metaphor for the unconscious mind), the abandoned clock towers he sees, their faces without hands (63), or a chalk-white colonnade visited by Kerans that reminds him of an Egyptian necropolis (68).

The Drowned World uses 'the external transformation of the urban landscape to reflect and marry with the internal transformation' of Kerans, who is the only character in the novel to fully embrace both of these transformed worlds (Sellars \& O’Hara, 2014: 90). Indeed, as Ballard has also argued, perhaps the extreme urban transformation he depicted in The Drowned World - by any other estimation a catastrophe - might provide the only environment in which genuine human transformation might occur (202-203). Yet, there is no denying the extreme subjectivity of Ballard's future drowned city, a post-urban environment in which conventional social relations are completely severed. It is clear that Ballard believed that individual psyches have the potential for transformation, but this occurs in almost total isolation. There is also a sense in which Ballard's vision elides human responsibility for the transformed environment - it is the sun that causes London to be drowned, not human activity. As Trexler (2015: 28) has argued, this has proved a problematic precedent for fictions that address anthropogenic climate change because it 'acts as a terrific form of compression, homogenizing a whole world of ecological and climatic variation into a single, distorted disaster'. Yet, vivid images of submerged cities that draw their inspiration from Ballard's novel have characterised a number of recent climate-change fictions. Paolo Bacigalupi's The Drowned Cities (2012) is similar to The Drowned World in both its self-explanatory title and also the fact that the identity of the city it depicts - Washington, D. C. - is, like Ballard's future 
London, only revealed towards the end of the novel. Mirroring Ballard's post-diluvian London, the American capital has been overtaken by tropical vegetation, but, unlike Ballard's uninhabited city, this one has become home to rival warlords and scavengers. With its Chinese counterpart, Shanghai Island, remaining a bastion of civilization, Bacigalupi inverts conventional contemporary Western assumptions about America's enlightened democracy versus China's repressive political regime. No less savage in its politics, but more satirical, is Will Self's The Book of Dave (2008), where London, 400 years into the future, has been submerged by 100 metres of sea water, turning the city into an archipelago. With its social and political life based on the eponymous 'Book of Dave', the rantings of a London cabbie that are revealed in the segments of the book set in our present-day era, the imagined future world extends Dave's bigoted views, cockney dialect and text messages to form a entire social and linguistic world. Yet the novel's fantastic premise is also grounded in Self's own encyclopaedic knowledge of London, one that closely links this future city to the London in the here and now, with all its current dystopian tendencies - increasing social division, the rise in right-wing nationalism, and the globalisation of finance and culture - imagined to be played out as a reactionary future in extremis. Although the submerged cities in these novels host social lives we can barely imagine, they nevertheless draw those lives firmly within the orbit of the familiar, whether through landmarks such as the Washington Monument and White House in The Drowned Cities, or the myriad familiar-yet-different street and place names of a future London in The Book of Dave. As already stated in the introduction to this article, the play of strangeness and familiarity in such future-orientated fictional narratives is important because it disrupts the ways in which we relate to the familiar real urban world, thus shifting the parameters of what that real might actually be. In Rancière's estimation, this kind of estrangement opens up new realms of possibility because it 'rearranges the rules of the game by making two things interdependent: the blurring of the borders between the logic of facts and the logic of fiction' (Rancière, 2004: 36).

In contrast to these post-diluvian future cities, some recent climate-change fictions have used the image of flooded cities to articulate a different kind of narrative, namely that of flood-asduration. These have sought to imagine social relations in future cities that are being slowly transformed by rising sea levels and notable examples include Melbourne in George Turner's The Sea and Summer (published in 1987 when awareness of climate change was only just emerging), Bangkok in Bacigalupi's The Windup Girl (2010), and London in Maggie Gee's The Flood (2004) and Stephen Baxter's Flood (2008). In all of these city-based climate-change fictions, the relationships between characters in a transforming urban environment take precedence over dramatic descriptions of submerged cities. Yet, they do so for varied reasons. In The Sea and Summer the emphasis is on relations between sharply-divided classes - as sea levels inexorably rise, Melbourne's tiny urban elite retreat to high ground in secure compounds, while the $90 \%$ poor and unemployed eek out a third-world existence in flood-prone tower blocks. The Windup Girl focuses on the relationships between humans and their artificially-created cousins (the windup girl of the book's title) in a future Bangkok, an island-city ringed by enormous defensive sea walls protecting it temporarily from a flooded outside world in violent turmoil (Abbott, 2016: 165-68; 
Trexler, 2015: 211-19). Gee and Baxter's London-based novels centre on near-contemporaneous urbanites dealing with an ongoing crisis - unending rain and rising flood waters - and an impending catastrophe, namely, an apocalyptic tsunami in The Flood that engulfs the entire city in the final moments of the novel, and an even-greater apocalypse in Flood as sea levels continue to rise until they submerge the entire planet. In contrast to The Drowned World, the cityscapes in these novels function more as backdrops to social interactions and character development and therefore lack the hallucinatory power of Ballard's post-diluvian London; yet, this is precisely the result of their emphasis on the relationships between people in a transformed urban environment rather than the intense subjectivity of a solitary inhabitant. As Trexler (2015: 117) has argued in relation to Gee's The Flood, this focus on social relations suggests that 'human connections are wholly dependent on material place, that climate change has decimated the characters with whom the reader has identified, and that it also threatens to kill real people we love in this world'. In this way, the near-future London depicted in The Flood draws us back to the present-day city that we know and experience, rather than forward to a transformation that is only seen as destructive and diminishing.

Taken together, climate-change fictions that imagine future drowned cities invite multiple ways of working through possible apocalyptic scenarios. Although most of these fictions exaggerate the scale and shorten the timescale of future flooding for dramatic effect, they do so in order to galvanise the apocalyptic imagination towards redemptive rather than reactive ends, whether the transformation of the individual psyche when confronted with radical change or social relations during the progression towards catastrophe. These multiple ways of apprehending urban futures are important because they flag up the fact that discourses on climate change are inevitably both real and fabricated, relying as they do on the work of the imagination as much as scientific enquiry; many non-fictional accounts of climate change also draw on exaggerated apocalyptic imagery for rhetorical effect (Lynas, 2008; Oreskes, 2014). Climate-change fictions also point to the need for the human imagination to think through adapting to the future effects of climate change on cities. Indeed, these novels demonstrate a wealth of adaptive strategies taken up by human subjects in the face of catastrophe, from the total acceptance of the solitary contemplative in The Drowned World to the communal struggles of The Flood and The Sea and Summer and other contemporary novels.ii Finally, even as these fictions project the city forward in time - whether the far future of Ballard's novel or the near-contemporary London of The Flood - they nevertheless, through their narratives and characters, draw readers back into the world they inhabit in the present, a world that is already set on a future course that they will - individually, collectively, and all together with the changing climate - play a part in bringing into being. In this sense, they can contribute much to what Guattari (2000) has identified as an ecology of mind. For Guattari, cultivating a mental ecology is just as important as one that focuses on environmental or social concerns, and he sees this as primarily achieved by abandoning 'scientific (or pseudo-scientific) paradigms and returning to aesthetic ones' (37). This may seem like an extreme reaction against scientific enquiry which, after all has led us to the point of knowing about climate change, but for Guattari, it is science that 
has denigrated and almost extinguished the value of human subjectivity and the aesthetic dimension of human experience (28). For the ecological revolution that is urgently required to address climate change to occur, the 'sensibility, intelligence and desire' of the human mind must be reshaped, just as much as the political, economic, and social aspects of the human world. It is precisely in the realm of the imagination that human subjectivity might begin to build its own resilient ecology of mind. Such mental resilience on the part of the urban populace is equally important as that of the built fabric of the city - whether buildings or infrastructure - in the face of the threats and transformations that will be brought about by climate change.

\section{Postcards from the future}

One of the most enduring images of London in ruins is an engraving by Gustave Dore from 1872 (Figure 1) - the final illustration in Blanchard Jerrold's book London: A Pilgrimage. Depicting what was then the world's largest city and the centre of a global empire, Doré's image was a late expression of the nineteenth-century obsession with the figure of the 'New Zealander', an imagined New World successor to the British who would, in the far distant future, come to gaze upon the ruins of London just as Victorian travellers gazed upon those of ancient Rome (Nead, 2000: 21215; Skilton, 2004). It is also a powerful image of submergence - the city slowly succumbing to ruin from above (its buildings sinking into the ground) and below, from the waters of the river Thames, long released from their human-made embankments. Tapping into late-nineteenth anxieties about both imperial decline and London's seemingly intractable social divisions, this image was an early precursor to cinema's enduring obsession with picturing urban destruction. Thus, apocalyptic flood disaster films, from Deluge (Felix E. Feist, 1933) to The Day After Tomorrow (Roland Emmerich, 2004), use New York's landmarks, such as the Statue of Liberty, in the same way as Doré's image uses the sunken pillars of Blackfriars Bridge and the ruined dome of St Paul's cathedral beyond to provide memorable visual reference points for an otherwise wholly unfamiliar apocalyptic narrative (Page, 2008: 74-6, 89-91, 196, 220-26; Withington, 2014: 107-16). At the same time, the sense of flood waters as restoring untamed nature back to the city resonates with cinematic images of post-apocalyptic cities, such as New York City in I am Legend (Francis Lawrence, 2008) and London in The Girl with all the Gifts (Colm McCarthy, 2016). Indeed, these two aspects of deluge imagery - the apocalyptic and post-apocalyptic - mirror the two strands already identified above in relation to climate-change fictions, namely the imagination of cities after a catastrophic flood and those that focus on the apocalyptic flooding event or events themselves. As with fiction, these images tend to emphasise, on the one hand, the experiences of a solitary survivor (the New Zealander in Doré's image) and, on the other, the attempts by urban inhabitants to come to terms with flooding, even if, in the cinematic tradition, this is usually focused on rebuilding cities rather than adapting to their submergence.

\section{[Insert Figure 1 here - portrait]}


In relation to more recent predictions about the impact of sea level rises on low-lying cities, visual imagery is characterised by two dominant viewpoints, namely the view from above and the view from below. The first category includes scientifically-produced images, such as predictive flood maps issued by the UK Environment Agency (Daily Mail, 2011) - conventional map views of cities like London overlaid with swathes of blue indicating areas at risk from future flooding - and more creative adaptations of maps seen in Jeffery Linn's series of sea rise maps, in which the artist has shown how world cities such as London, Los Angeles, Vancouver and Hong Kong would virtually disappear if sea levels rose by $66 \mathrm{~m}$, the highest level currently predicted by the IPCC (Linn, 2016). Views from above also include bird's-eye views of cities showing how sea level rises might alter the sky, shore, and riverscapes of iconic landmarks, for example, the Houses of Parliament in one image from the artists Didier Madoc-Jones and Robert Graves's 2010 series Postcards From the Future, iii and John Upton's digital photomontage of Manhattan skyscrapers used in Al Gore's polemical film An Inconvenient Truth, released in 2007. There is no doubting the rhetorical effect such imagery has, providing, as it does, a dramatic at-a-glance picture of what cities might look like if flooded by a significant rise in sea levels; yet, these images distance viewers from the catastrophic effects of such flooding by showing only the end results in the far future and also, in the case of many of the images from Postcards from the Future series, by casting the future inhabitants of inundated cities as racially 'other' (Baldwin, 2015). Indeed, what we see in these images are effectively urban stage sets - cities emptied of inhabitants bar orientalised migrants and submergence cast as an inevitable and unstoppable apocalyptic event, even as the process leading to flooding on such a scale would take centuries to work itself out.

\section{[insert Figure 2 here - portrait]}

Views from below actually situate viewers beneath the flood waters - a discomforting position because such an environment would be much more hostile to human inhabitation than the dry land that would remain above the flood. They include digital images of submerged urban landscapes, such as Francois Ronsiaux's Times Square in New York enveloped in submarine blue (Azzarello, 2015) and Nickolay Lamm's similarly rendered image of Miami under a 25ft rise in sea levels (Bennett-Smith, 2013). These images present desolate urban vistas, devoid of any life bar the observer, even as the flood waters are rendered crystal clear. In contrast, in one of a series of five images produced by the UK media production studio Squint/Opera 2, London's future flood waters support a rich marine ecosystem (Figure 2). Looking up from the bottom of a new shallow sea towards the half-submerged church of St Mary's on London's Strand, this image provides an unfamiliar counter to the otherwise predominantly pessimistic representations of urban futures underwater (Fairs, 2008; Gandy, 2014). Exhibited as part of a series at the London Architecture Festival in 2008, this view from below offers a sense of optimism - in Squint/Opera's London of the future, 'far from being a tragedy, the floods have brought about an improved way in life in the capital' (Fairs, 2008). Yet, just how such an improved way of life will come about is far from clear in the image, bar the inclusion of a manned boat that suggests a tranquil human presence. The image's depiction of a thriving marine ecosystem in pure waters is entirely at odds with most 
literary fictions that represent the progress of future urban floods. Thus, in Gee's The Flood (2004: 189), the rising waters smell 'of rot, of toilets'; in Turner's The Sea and Summer, they are filthy, 'full of floating, nameless debris, stinking rubbish' and 'soft slops of slime that touched and clung'; while in Baxter's Flood (2008: 172, 244), they are choked with bodies and wastes, 'murky greybrown', 'slick with oil' and 'littered with garbage, plastic scraps and bursting bin liners'. Mirroring the experience of many dealing with the aftermath of real urban floods, when raw sewage often rises up from underground sewers, these fictions undermine the image of any future flood waters as restorative or regenerative.

\section{[insert Figure 3 here - landscape]}

At first glance, the flood waters in Alexis Rockman's painting Manifest Destiny (2003-04; Figure 3), seem to be supporting an equal abundance of life as Squint/Opera's image of a bucolic flooded London (Figure 2).iv Indeed, they do, but this is not life as we know it; rather an extraordinary array of organisms made up of a mixture of recognisable flora and fauna (algae, coral, seals, lampreys, carp, an enormous jellyfish, sunfish and lionfish underwater; and gulls, cormorants, egrets and pelicans above) and strange new bioengineered species, including fish sprouting pustules, outsized deadly viruses (identified by the artist as HIV, West Nile, and SARS) and other bacteria-like creatures and mutant crustaceans (Rockman, 2005: 6; Page, 2008: 22628). Indeed, most of the non-human life included in Manifest Destiny seems alien, for this is a split-level panorama of the New York district of Brooklyn in the year 5000, after global warming has not only submerged the city but also transformed its climate from temperate to tropical. Despite the fact that the landscape is empty of human beings, the legacy of the latter is evident everywhere. Here, the remains of the human-constructed environment - the Brooklyn Bridge on the right, vestigial skyscrapers in the distance and, perhaps most strikingly, the city's subterranean infrastructure of tunnels, storage vaults, sewers, and gas and water pipes - not only linger in the far distant future, but have played a key role in the evolution of the organisms that now inhabit them. Scattered throughout the image are also the products of present-day accelerated capitalism that mock the hubris that characterises our technological age - a floating oil barrel, a sunken oil tanker, stealth bomber and submarine. Finally, Rockman also includes in his painting the remains of projects yet-to-be built (in 2004), most notably dykes and sea walls meant to protect the city against sea level rises, but which, in the far distant future, have long been overwhelmed by the inexorable flood waters.

In its extraordinary attention to detail and concern with accuracy - during the process of creating the work Rockman consulted with palaeontologists, biologists, archaeologists and architects - Manifest Destiny not only presents a dire warning to a pervasive contemporary reluctance to change the destructive course of industrial capitalism, but also a compelling image of how the human-built world will continue to influence the evolution of the environment long after humans themselves have disappeared. With its mixture of tropical and bio-engineered flora and fauna, the intensity of its sunlight, and the absence of the human, Rockman's vision mirrors Ballard's hallucinogenic image of a future London in The Drowned World. Yet, unlike that novel, it 
points us back to ourselves in the here-and-now, challenging us to think more seriously and more imaginatively about the long-terms effects our collective actions now will have on the world to come. As such, Manifest Destiny chimes strongly with the emergence of the idea of the Anthropocene in the 2000 s as defining a new epoch in geological time in which human activity, and particularly an accelerating urbanism, is as 'geologic' a force as natural ones (Chakrabarty, 2009: 206-7). Even though the painting transports the viewer to a barely conceivable 3,000 years into the future, it nevertheless spells out clearly the connections between our own time and this long span into the future. It also breaks down the entrenched humanist distinction between natural and human history; in Manifest Destiny, both the future of the city and of nature are thoroughly intertwined. As such, the painting clearly flags up the need to think through those connections today and to recognise that they are already putting us on the road to the future envisaged in the painting. However, as the painting's ironic title suggests, such a future is not inevitable; rather, Manifest Destiny invites us to think through how our own small actions are interwoven with the world and how they might be changed to co-create a more sustainable future. The painting also calls into question the current tendency to combat urban inundations with more effective flood defences, as seen in both post-Katrina New Orleans (Burnett, 2015) and in many towns in the UK affected by recent flooding. ${ }^{v}$ With New York's own future-built flood defences swallowed by the sea, the painting clearly shows the folly of such an approach in its unwillingness to make the deeper changes to both mitigate and adapt to global warming, a point that is perhaps at last being recognised in a shift towards ideas of resilience in the UK government's 2016 National Flood Resilience Review (HM Government, 2016). Such warnings are also characteristic of the climatechange fictions discussed previously: the vast sea walls that surround Melbourne in the midtwenty-first century in The Sea and Summer are eventually overwhelmed; the relocation of New York to higher ground in Flood proves fruitless; and the seemingly impregnable walls and pumps encircling Bangkok in The Windup Girl are finally destroyed by the inhabitants' inability to peacefully resolve their conflicts.

How we negotiate the prospect of a future urban life radically transformed by flooding is critical to the formation of the imagination today. In both literary and visual depictions of submerged urban futures, the intention is clearly to engage our imaginations in thinking through such possibilities. But does such apocalyptic deluge imagery have the effect of paralysing us in the face of overwhelming, and perhaps inevitable, catastrophe, as Swyngedouw (2010; 2013) has argued? Even though the urban transformations depicted in many fictions and images of the effects of future climate change might be extreme or exaggerated, they nonetheless provide intimations of what might be required for genuine human and social transformation to occur. This idea closely reflects the original meaning of the word 'apocalypse', namely the Greek apokalupsis meaning revelation or disclosure. In this sense, apocalyptic urban drownings in texts and images are not oriented towards a terminal point in the future but rather produce an ongoing revelation that transforms. As Skrimshire (2010: 228) has highlighted, the notion of apocalypse as revelation is embedded in how climate change is portrayed today, namely 'as a discourse of the future that is at 
once the revelation of ends, or limits, as well as the symbol of necessary transformation itself'. What images in particular contribute to this discourse are representations that open up an ambiguous aesthetics where a transformed future urban environment can be temporarily lived in by readers/viewers in order to establish resonances between their inner and outer worlds. Following Rancière's understanding of aesthetics as the visual forms of the world that present themselves to our sensory experience, these images can be understood as interventions that disrupt the existing aesthetic field, rendering it more heterogeneous and therefore richer in its potentiality. These images not only affect how we sense the urban world now but also how we negotiate our relationship to a future urban reality that they open a window onto: a coming 'real' that 'must be fictionalized in order to be thought' (Rancière, 2004: 38). As images like Manifest Destiny suggest, such a future urban environment will be co-produced by both human and non-human forces, each with their own histories and future trajectories, whether, the short spans of individual and collective human history or the 'deep' geological and ecological time of the earth. As Chakrabarty (2009: 213) has forcefully argued, the realisation that anthropocentric climate change will transform the future environment necessarily 'requires us to bring together ... the planetary and the global; deep and recorded histories; species thinking and critiques of capital'.

\section{Submarine cities}

Although the climate-change fictions and imagery examined so far describe urban environments radically transformed by rising sea levels, their architectures tend to remain cast in relatively conventional terms: familiar concrete slum-like tower blocks and skyscrapers in The Sea and Summer, The Flood and Flood sink beneath the flood waters rather than being adapted in terms of their design; cities are abandoned for giant cruise ships that eventually prove just as vulnerable in Flood; while even the futuristic architectures included in Manifest Destiny, such as Santiago Calvatrava's proposed remodelling of the Washington Bridge in New York, are shown to be wholly inadequate responses to the threat of climate change. ${ }^{\text {vi }}$ By contrast, in architectural practice, some have imagined and even partially realised urban communities that adapt to rising sea levels by floating on water (Miéville, 2007; Olthus \& Keuning, 2010); while others envisage cities creating 'soft' edges to peacefully coexist with what are projected to become permanently flooded zones (Beatley, 2014; Barker \& Coutts, 2016). These approaches attempt to mitigate rising sea levels in urban areas by accommodating water in innovative ways; yet, they tell us very little about how architects might respond to buildings becoming partially or completely submerged. How might future urban communities embrace the sea as an environment to be lived in rather than on? Just as the images discussed above often fail to produce convincing representations of the submarine urban environments that will likely be newly-created by rising sea levels, so architecture has often struggled to envisage let alone realise underwater habitats. As Sandra Kaji-O'Grady and Peter Raistrick (2005: 448) have argued, the submarine environment is one that is as hostile to human habitation as alien planets or outer space; underwater, the human body is extraordinarily 
vulnerable, not only losing its ability to respire naturally but also its orientation to the vertical, to the horizon.

Yet, despite these challenges, the exploration and inhabitation of the submarine environment has long held a fascination for many writers and designers, from Jules Verne's Twenty Thousand Leagues Under the Sea (1870) to the development of scientific and military underwater habitats in the second half of the twentieth century, whether research laboratories like the US-Navy-designed Sealab series in the 1960s, or Jacques Cousteau's experimental Conshelf communities. Stimulated by these technological developments, architects in the 1960s began to imagine the building of entire cities underwater. These included a submarine hotel complex displayed as part of General Motors's 1964 Futurama exhibit at the World's Fair in New York (Samuel, 2007: 106-109), Warren Chalke's interconnecting spheres in his Underwater City project for Archigram in the same year (Sadler, 2005: 38-41), and Jacques and Edith Rougerie's projects in the early 1970 s for a submarine village, museum, and a deep sea research laboratory (Rougerie, 1974).

In recent years, a renewed interest in underwater living has been stimulated by both the threat of rising sea levels and the extreme overcrowding of existing terrestrial cities. In the popular media, National Geographic produced City Under the Sea (2011), a pseudo-documentary charting the construction of an imagined future submarine city built in response to global warming and comprised of communal domes on the sea bed linked to rows of living pods for the 'aquanaught' families. In architectural discourse, designers have published their own proposals for underwater cities of the future, including Phil Pauley's Sub-biosphere 2 project, a semi-submerged settlement of eight biodomes connected to a central spherical support structure (Garvey, 2010); Shimizu Corporation's Ocean Spiral scheme from 2015, a 500-metre wide sphere underwater that would support a tower filled with homes, shops, offices, a hotel and research facilities (Shimzu Corporation, 2014); and Ocean City by Alanna Howe and Alexander Hespe (Hespe \& How, 2010), exhibited as part of the Australian Now + When entry at the 2010 Venice Biennale, and made up of clusters of floating platforms with submerged living quarters that resemble jellyfish in their design. In thrall to a technological optimism in the face of ecological crisis, as well as a libertarian politics that seeks to create new autonomous territories for social elites, these projects demonstrate the enduring appeal of the idea of the sea as a hostile environment to be conquered - a frontier for the melding of individual freedom and unfettered technological innovation (Miéville, 2007). Although these projected cities claim to create truly sustainable habitats - self-sufficient communities that recycle all wastes, generate their energy entirely from renewable sources, and grow their own food they nevertheless fail to articulate any kind of progressive social programme, instead falling back on the elitist libertarian ideals that have characterised utopias of this kind from the early twentieth century onwards. They also fail to engage with the sea as a dynamic environment, one that we know is rapidly changing as it absorbs the carbon dioxide we continue to release into the atmosphere. As the recent wave of mass-coral bleaching events in Australia's Great Barrier Reef testify, the sea is becoming both warmer and more acidic, factors that will irrevocably alter the 
entire marine ecosystem. To assume that humans can colonise a pristine new environment (as most of these projects do) is a dangerous illusion, one that has been parodied in $2 \mathrm{~K}$ Boston's video game Bioshock (2007), in which the high-tech submarine city Rapture turns from a libertarian dream into a savage dystopia (Anderson, 2015: 205).

\section{[insert Figure 4 here - landscape]}

Yet, there are currents within the architectural imagination of submerged urban environments that suggest a richer engagement with the sea as it might become in a warming climate. Back in 1970 - as many first became consumed with fear about the likelihood of grim urban futures of environmental pollution and overpopulation - the architect Wolf Hilbertz and artist Newton Fallis first sketched out a proposal for their Autopia Ampere project (Figure 4), a marine city that would literally grow out of the sea at Seamount Ampere, a site of shallow waters situated about halfway between the Madeira Islands and the tip of Portugal (Hilbertz, 1970; Cureton, 2013). The city would begin as a series of underwater wire-mesh armatures anchored on top of a sea mountain. Once in place, the wire mesh would be connected to a supply of low-voltage direct current produced by solar panels. Over time, electrochemical reactions would draw minerals from the sea to the armatures, creating walls of calcium carbonate - a natural spiral-shaped dam that would emerge from the sea to both protect and contain a sizeable population from the otherwise hostile marine environment. Although Autopia Ampere was never realised, Hilbertz's visionary 'growing' architecture eventually led to his developing, in collaboration with the coral scientist Thomas Goreau, of 'Biorock' in 1979 (also known as Seacrete or Seament), a substance formed by the electro-accumulation of materials dissolved in seawater (Hilbertz et al., 1979). This material has found a viable use in the restoration of damaged coral reefs, with the Biorock grown to attract corals and other marine life in order to rebuild submarine ecosystems and make them more resilient to changes in the constitution and temperature of sea water (Spenhoff, 2010). In a world where coral has already become one of the first casualties of climate change, Biorock is likely to become an important way of creating new submarine environments out of the ruins of the old. In this sense, Hilbertz's submarine-grown building material is very different from any proposed in more conventional designs for underwater habitats; because it is able to adapt to changes in the constitution of the sea, it is a material that is ideally suited to the age of the Anthropocene. It provides a pertinent model for an urban design practise that seeks to adapt to the waters that will eventually inundate many cities. As many of the future fictions discussed above make clear, such water will not be pristine and undefiled, but rather filled with a host of human-made substances, whether dissolved carbon dioxide, indestructible plastic, or urban wastes. It may become evident that the only building material that will be able to adapt to submerged cities will be one, like Biorock, that can be grown in the transformed environment.

Hilbertz's Biorock is an important precursor to the current trend in architectural design that seeks to engineer biomorphic materials that mimic nature, thereby questioning conventional interpretations of what sustainable and resilient architecture might be (Agkathidis, 2016; Pawlyn, 2016). Such an approach has led to some radical urban design proposals that directly address the 
prospect of rising sea levels. The synthetic biologist Rachel Armstrong (2009) has proposed using protocells (chemical agents that behave in lifelike ways) to grow an immense artificial limestone reef structure under Venice to save the city from sinking into the sea. In a different vein, CRAB Studio (led by architects Peter Cook and Gavin Robotham) addressed the prospect of a future flooded London with their Soak City project (2009), a series of towers sited in East London that would be hand-built from the remains of former buildings and other salvaged materials (Cook, 2013: 86-87). vii The towers themselves were developed from Cook and Robotham's earlier projects for vegetated dwellings, which conceived of buildings taking plants into themselves as part of their ongoing evolution and growth, eventually resulting in hybrid architectures that meld nature and artifice (Cook, 2016: 142-45). Enveloped in the dense vegetation that has grown out of the flood waters themselves, the Soak City towers suggest a future semi-submerged urban environment that allows continued inhabitation by means of a radical form of adaptation. Soak's City's vegetated towers mirror the verdant ruins of the Brooklyn Bridge in Manifest Destiny and the vine-choked apartment blocks and offices in Ballard's The Drowned World, but, in contrast to both, also envisage a thriving human presence that responds to the flooded city with complete acceptance, resulting in a dynamic coexistence with the transformed urban environment.

The kind of architectural conjecture seen in Hilbertz's Autopia Ampere and Crab Studio's Soak City radically departs from conventional notions of building as deriving from the fabrication of construction materials; rather, making in these projects is fundamentally a process of growth. As such, it chimes strongly with the arguments put forward by anthropologist Tim Ingold (2013: 21), who has sought a renewal of the notion of design as a process of making that intervenes in 'worldly processes that are already going on, and which give rise to the forms of the living world that we see all around us'. In Ingold's view, architects do not impose their designs on the world as if those two domains were entirely separate; rather they add their 'own impetus to the forces and energies [already] in play'. In relation to climate change and the prospect of future submergence, urban designers must face head on the challenge of designing with these future conditions, rather than falling back on the notions of mitigation and containment that continue to characterise mainstream approaches.

\section{Conclusion}

As I have demonstrated in this article, it is vital to think through what connects the literary, the pictorial and the architectonic in relation to urban futures and climate change. All three modes of expression are grounded in an imaginative apprehension of the world; and all three disrupt an existing aesthetic field dominated by instrumental thinking in order to create new possibilities that might be sensed and incorporated into an emerging 'real'. Of course, within this generalised purpose, they play themselves out in very different media and to diverse audiences. Yet, it is my belief that they are enriched by a mutual engagement: novelists use architecture as a frame for urban environments disrupted by climate change, drawing out the social and political narratives 
imagined in those environments; artists create images of urban flooding that complement fiction by visualising transformed cities that are nevertheless grounded in familiar landmarks or views that we already know; while architects work through how to build anew in the submerged urban worlds anticipated through fiction and art. Moreover, as Steven Graham (2016: 388) has elucidated, these connections between fiction, art and architecture are already apparent in our image-saturated contemporary milieu. Thus, there is no clear separation between the fictional cities explored in this article and the material cityscapes that are being constructed, lived in and experienced today. The increasingly complex circuits of information exchange that we inhabit undermine any notion of a 'real' life that exists in isolation of its representation in fiction and media. Our task therefore is to work through the interactions between the fictive and the real and to see the resulting hybrid aesthetic field as a powerful tool in helping us to work through the complex range of implications inherent in future urban scenarios. The scientific discourse of climate change may attempt to predict likely outcomes of rising sea levels on cities using empirical evidence, but those predictions are usually stated in bald statistical terms, avoiding engagement with the emotional consequences of presenting such alarming statistics. Climate-change fictions whether they take the form of texts, images or architectural conjecture - fill the gap here, making room for other kinds of forecasts, not of a predictive nature, but centred on the creation of future narratives - stories that we can latch onto in terms of imagining what it would be like to live in these possible future urban worlds.

In addition, all of the imagined future cities presented in this article rest on the fundamental assumption that we need to accept the changes that will come as a result of climate change and to adapt to those changes. Of course, these fictions are not suggesting mere resignation in the face of the threat of rising flood waters, or that political, economic and social life should remain as it is; rather, they demonstrate that change - the kind of transformational change that is and will be undoubtedly required of us in the face of a new global climatic order - can only come about by imagining how to live that change, rather than merely accepting that it is necessary. This is what underlies Guattari's argument that ecology in its broadest sense is both imaginative and anticipatory. In this sense, the imagination of urban futures is not simply a game to be played - a diversion from life in the real urban world - but rather an essential way in which we can cultivate resilience for ourselves, not in order to wallow in pessimism or justify inaction, but rather the opposite - to nourish mental lives that resist the increasingly polarising political and social discourses that are emerging out of radically uncertain urban futures and the threat of catastrophe. In this understanding, the freedom to imagine the future is not a given - an inviolate inner space but one that must be seized hold of and protected at all costs. As both Guattari and Rancière have stressed, the cultivation of mental resilience is a fundamentally political act - an assertion of the right to be a free urban citizen. If we agree that our cities really are made and unmade in the imagination as much as in their material spaces - a meld of matter and mind - then imaginative texts, images and designs must mutually inform each other to encourage holistic ways of 
approaching how we think about the future prospect of urban submergence. This is how we incubate radical responses to it.

\section{References}

Abbott, C. (2016) Imagining urban futures: cities in science fiction and what we might learn from them. Wesleyan University Press, Middletown, CT.

Agkathidis, A. (2016) Biomorphic structures: Architecture inspired by nature. Laurence King, London.

Anderson, D. (2015) Imaginary cities. Influx Press, London.

Anon. (2014) Intergovernmental Panel on Climate Change 2013: the physical science basis, summary for policymakers [WWW document]. URL http://www.ipcc.ch/pdf/assessmentreport/ar5/wg1/WGIAR5 SPM brochure en.pdf (accessed 18 July 2016).

Armstrong, R. (2009) Architecture that repairs itself? Ted talk [WWW document]. URL https://www.ted.com/talks/rachel armstrong architecture that repairs itself?language=en (accessed 18 July 2016)

Azzarello, N. (2015) Architecture under water: Francois Ronsiaux images man's habitat post ice thaw. Designboom, 23 January 2015 [WWW document]. URL

http://www.designboom.com/art/architecture-under-water-francois-ronsiaux-imagines-manhabitat-post-ice-thaw-01-23-2015/ (accessed 18 July 2016).

Bacigalupi, P. (2010) The windup girl. Orbit, London.

Bacigalupi, P. (2012) The drowned cities. Atom, London.

Baldwin, A. (2015) Premediation and white affect: climate change and migration in cultural perspective. Transactions of the Institute of British Geographers 41: 1, 78-90

Ballard, J. G. (2009) Gewalt ohne ende. Die Zeit, 21 April 2009 [WWW document]. URL www.zeit.de/2005/37/Ballard interview (accessed 18 July 2016).

Ballard, J. G. (2011) The drowned world. 4th Estate, London. 
Barker, R., and R. Coutts (2016) Aquatecture: buildings designed to live and work with water. RIBA Publishing, London.

Baxter, J. (2009) J. G. Ballard's surrealist imagination: spectacular authorship. Ashgate, Farnham.

Baxter, S. (2008) Flood. Gollancz, London.

Beatley, T. (2014) Blue urbanism: exploring connections between cities and oceans. Island Press, London.

Bennett-Smith, M. (2013) Nickolay Lamm's sea level rise images depict what U.S. cities could look like in future. Huffington Post, 4 November 2013 [WWW document]. URL http://www.huffingtonpost.com/2013/04/11/nickolay-lamm-sea-level-rise-us-citiesphotos n 3062480.html (accessed 18 July 2016).

Bulkeley, H. (2013) Cities and climate change. Routledge, London and New York.

Burnett, J. (2015) Billions spent on flood barriers, but New Orleans still a 'fishbowl'. npr, 28 August 2015 [WWW document]. URL http://www.npr.org/2015/o8/28/432059261/billions-spent-onflood-barriers-but-new-orleans-still-a-fishbowl (accessed 18 July 2016).

Chakrabarty, D. (2009) The climate of history: four theses. Critical Enquiry 35, 197-222.

Cook, P. (2013) Looking and drawing. Architectural Design, 1 September 2013, 86-7.

Cook, P. (2016) Architecture workbook: design through motive. John Wiley, Chichester.

Cureton, P. (2013) Videre: drawing and evolutionary architectures. Materials. Architecture. Design. Environment 7.10, 16-27.

Daily Mail (2011) Our future underwater: terrifying new pictures reveal how Britain's cities could be devastated by flood water. Mail Online, 9 March 2011 [WWW document]. URL http://www.dailymail.co.uk/sciencetech/article-1363703/Our-future-water-How-devastatingfloods-swamp-major-cities.html (accessed 18 July 2016).

Donnelly, I. (2006) Atlantis: the antediluvian world. The Book Tree, San Diego. 
Fairs, M. (2008) Flooded London by Squint/Opera. Dezeen, 18 June 2008 [WWW document]. URL http://www.dezeen.com/2008/06/18/flooded-london-by-squintopera (accessed 18 July 2016).

Gandy, M. (2006) The drowned world: J. G. Ballard and the politics of catastrophe. Space and Culture 9.1, 86-88.

Gandy., M. (2014) The fabric of space: water, modernity and the urban imagination. MIT Press, Cambridge, MA.

Garvey, J. (2010) Sub Biosphere 2: designs for a self-sustainable underwater world. Gizmag, 23 June 2010 [WWW document]. URL http://www.gizmag.com/sub-biosphere-2-self-sustainableunderwater-world/15507/ (accessed 18 July 2016).

Gee, M. (2004) The flood. Saqi, London.

Graham, S. (2016) Vertical noir: histories of the future in urban science fiction. CITY 20.1, 382-99

Graves, R., and D. Madoc-Jones (2010) Postcards from the future. London Futures, 2011 [WWW document]. URL http://www.london-futures.com/2010/10/18/hello-world/ (accessed 18 July 2016)

Guattari, F. (2000) The three ecologies. Trans. Ian Pindar and Paul Sutton. Athlone, London and New Brunswick.

Harvey, D. (2000) Spaces of hope. Edinburgh University Press, Edinburgh.

Hespe, A., and A. Howe (2010) Venice Biennale: Ocean City. Australian Design Review, 26 October 2010 [WWW document]. URL https://www.australiandesignreview.com/features/1719-venicebiennale-ocean-city (accessed 18 July 2016).

Hilbertz, W. (1970) Towards Cybertecture. Progressive Architecture, 1970, 98-103.

Hilbertz, W. et al. (1979) Electrodeposition of minerals in sea water: experiments and applications. IEEE, Journal of Oceanic Engineering 4.3, 94-113.

HM Government (2016) National flood resilience review [WWW document]. URL https://www.gov.uk/government/uploads/system/uploads/attachment data/file/551137/national -flood-resilience-review.pdf 
Holthaus, E. (2016) Our planet's temperature just reached a terrifying milestone. Future Tense, 12 March 2016 [WWW document]. URL

http://www.slate.com/blogs/future tense/2016/03/o1/february 2016 s shocking global warm ing temperature record.html (accessed 18 July 2016).

Hulme, M. (2009) Why we disagree about climate change: understanding controversy, inaction and opportunity. Cambridge University Press, Cambridge.

Hutchinson, B. (2011) Port Authority paid architect Santiago Calatrava $\$ 500 \mathrm{G}$ for bridge plans it didn't ask for or use: report. New York Daily News, 27 April 2014 [WWW document]. URL http://www.nydailynews.com/new-york/port-authority-paid-santiago-calatrava-50og-bridgeplans-didn-report-article-1.1770941 (accessed 18 July 2016).

Ingold, T. (2013) Making: anthropology, archaeology, art and architecture. Routledge, London.

Jameson, F. (2008) Archaeologies of the future: the desire called utopia and other science fictions. Verso, London.

Kaji-O’Grady, S., and P. Raisbeck (2005) Prototype cities in the sea. Journal of Architecture 10.4, $443-61$

Kearney, R. (1991) Poetics of imagining: modern to postmodern. HarperCollins Academic, London.

Levitas, R. (2013) Utopia as method: the imaginary reconstitution of society. Palgrave, London.

Linn, J. (2016) Sea level rise maps. Spatialities 2016 [WWW document]. URL http://spatialities.com/category/sea-level-rise-maps/ (accessed 18 July 2016)

Lynas, M. (2008) Six degrees: our future on a hotter planet. Harper Perennial, London.

Nead, L. (2000) Victorian Babylon: people, streets and images in nineteenth-century London. Yale University Press, London and New York.

Machin, A. (2013) Negotiating climate change: radical democracy and the illusion of consensus. Zed Books, London and New York. 
Miéville, C. (2007) Floating utopias: freedom and unfreedom of the seas. In M. Davis (ed.) Evil paradises: dreamworlds of Neoliberalism. New Press, New York.

Olthus, K., and D. Keuning (2010) Float! Building on water to combat urban congestion and climate change. Frame, Amsterdam.

Oreskes, N. (2014) The collapse of civilization: a view from the future. Columbia University Press, New York.

Osborne, H. (2015) Sunken city of Igarata begins to emerge as Brazil's drought sees water levels plummet. International Business Times, 6 February 2015 [WWW document]. URL http://www.ibtimes.co.uk/sunken-city-igarata-begins-emerge-brazils-drought-sees-water-levelsplummet-1486951 (accessed 18 July 2016).

Page, M. (2008) The city's end: two centuries of fantasies, fears, and premonitions of New York's destruction. Yale University Press, London and New York.

Pawlyn, M. (2016) Biomimicry in architecture. RIBA Publishing, London.

Pelling, M. (2011) Adaptation to climate change: from resilience to transformation. Routledge, London and New York.

Plato (1892) The dialogues of Plato, vol. 3. Trans. R. Jowett. Oxford University Press, Oxford.

Rancière, J. (2004) The politics of aesthetics: the distribution of the sensible. Trans. G. Rockhill. Continuum, London.

Rockman, A. (2005) Manifest Destiny. Brooklyn Museum of Art, New York.

Rougerie, J., and E. Rougerie (1974) Habiter la Mer. L'Architecture D’Aujourd'hui 175.

Sadler, S. (2005) Archigram: architecture without architecture. MIT Press, Cambridge, MA.

Samuel, L. (2007) The end of the innocence: the 1964-1965 New York World's Fair. Syracuse University Press, New York.

Self, W. (2007) The book of Dave. Penguin, London. 
Sellars, S., and D. O’Hara (2014) Extreme metaphors: collected interviews, J. G. Ballard. 4th Estate, London.

Shimzu Corporation (2014) Ocean Spiral. Smimz [WWW document]. URL

http://www.shimz.co.jp/english/theme/dream/oceanspiral.html (accessed 18 July 2016).

Skilton, D. (2004) Contemplating the ruins of London: Macaulay's New Zealander and others. Literary London 2.1 [WWW document]. URL http://www.literarylondon.org/londonjournal/march2004/skilton.html (accessed 18 July 2016).

Skrimshire, S. (2010) Eternal return of apocalypse. In S. Skrimshire (ed.), Future ethics: climate change and the apocalyptic imagination. Continuum, London.

Spenhoff, A. (2010) The Biorock process: picturing reef building with electricity. Global Coral Reef Alliance, 2010 [WWW document]. URL

http://www.globalcoral.org/Biorock\%2obooklet\%20online\%20version\%201.4.pdf (accessed 18 July 2016).

Stern, N (2006) Stern Review: The Economics of Climate Change [WWW document]. URL http://mudancasclimaticas.cptec.inpe.br/ rmclima/pdfs/destaques/sternreview report complet e.pdf (accessed 18 July 2016).

Suvin, Darko (1972) On the poetics of the science fiction genre. College English, 372-82.

Swyngedouw, E. (2010) Apocalypse forever? Post-political popularism and the spectre of climate change. Theory Culture Society 27, 213-30.

Swyngedouw, E. (2013) Apocalypse now! Fear and doomsday pleasure. Capitalism Nature Socialism 24.1, 9-18.

Trexler, A. (2015) Anthropocene fictions: the novel in a time of climate change. University of Virginia Press, Charlottesville and London.

Turner, G. (2013) The sea and summer. Gollancz, London.

Vidal R., and I. Cornils (eds) (2014) Alternate worlds: blue-sky thinking since 1900. Peter Lang, Oxford. 
Watson, J., and Adams, M. (2010) Design for flooding: architecture, landscape, and urban design for resilience to climate change. John Wiley \& Sons, London.

Withington, J. (2013) Flood: nature and culture. Reaktion, London.

Yusoff. K., and J. Gabrys (2011) Climate change and the imagination. Wiley Interdisciplinary Reviews: Climate Change 2.4, 516-34.

\section{$\underline{\text { List of Illustrations }}$}

Figure 1 Gustave Doré, 'The New Zealander'. Wood-engraved print in Blanchard Jerrold, London: A Pilgrimage (London, 1872).

Figure 2 'St Mary Woolnath - Rich Pickings', digital image from the series Flooded London, 2008. Reproduced by permission of Squint/Opera.

Figure 3 Alexis Rockman, Manifest Destiny, 2003-04. Oil on board. Smithsonian American Art Museum. Reproduced by permission of Alexis Rockman.

Figure 4 Paul Cureton (after Newton Fallis), perspective view of Autopia Ampere, 2013. Pencil and ink on paper. Reproduced by permission of Paul Cureton.

\section{NOTES}

The work presented here forms part of a larger independent research project on urban futures and the imagination, supported in its early stages by an Independent Scholar Research Fellowship from the Independent Social Research Foundation. I am grateful to Matthew Gandy and the anonymous reviewers who provided such constructive feedback on an earlier draft of the article, and to Richard Breen, Paul Cureton, Marrikka Trotter and Jason Nguyen for comments and advice on the work of Wolf Hilbertz. Thanks also to Paul Cureton, Alexis Rockman, and Squint/Opera for kindly giving me permission to reproduce their work. A small section of this article was published in revised form in my book The Dead City: Urban Ruins and the Spectacle of Decay (London: IB Tauris, 2017). 
i The sunken cities off the coast of Alexandria were the subject of the exhibition Sunken Cities: Egypt's Lost Worlds held at the British Museum, London, 19 May - 27 September 2016.

ii Other notable examples of city-based climate fictions that use the flood-as-duration motif are Donna McMahon's Dance of Knives (2001), set in a flooded Vancouver; Kim Stanley's Robinson's Forty Signs of Rain (2004), the first in his Science in the Capital trilogy, and set in Washington DC; Saci Lloyd's Londonbased The Carbon Diaries 2015 (2009) and its 2010 sequel; and David Brin's Existence (2012), which takes place in the Huangpu estuary on the edge of a flooded Shanghai. Robinson's novel, New York 2140 (2017), which is set in a flooded future New York City, was published too recently for inclusion in this article. iii The series of digital images were presented as large-scale back-lit transparencies in the exhibition Postcards from the Future at the Museum of London, October 2010-March 2011.

iv Manifest Destiny was first exhibited in 2004 at the Brooklyn Museum of Art, who had commissioned the work. It has subsequently been acquired by the Smithsonian American Art Museum in Washington DC.

v On responses to the recent UK floods, see the 2016 report published by the Department for Environment, Food \& Rural Affairs, and the Environment Agency at https://www.gov.uk/government/news/70om-boostfor-flood-defences-brings-150m-more-for-yorkshire-and-cumbria (accessed 18 July 2016).

vi During the production of Manifest Destiny, Calvatrava's scheme was commissioned by New York's Port Authority, only to be controversially rejected by the Authority's commissioners in 2011 (Hutchinson, 2014). vii See http://www.crab-studio.com/soak-city.html for the complete series of renderings of Soak City. 